\title{
MYCOPLASMA GALLISEPTICUM AND STAPHYLOCOCCUS AUREUS INFECTION IN OSTRICH (STRUTHIO CAMELUS) IN MATROUH GOVERNORATE
}

\author{
Oraby; F.A.I. *and Hassan, A.M. ${ }^{* *}$ \\ * Matrouh laboratory and ** Department of mycoplasma, Animal Health Research \\ Institute, Dokki, Egypt).
}

\begin{abstract}
Ostrich farms in Matrouh Governorate were investigated for the detection of mycoplasma infection. Mycoplasma could be isolated from ostriches suffered from respiratory troubles, arthritis and conjunctivitis. The highest incidence of infection was found in winter at age of 10 month (21.74\%), followed by fall at age of 71/2 (17.24\%), while in spring at age of 11/2 was the least (9.38\%).

All the isolated strains were identified as M. gallisepticum. The present study is considered the first record for the isolation of M. gallisepticum from ostriches in Egypt.

Moreover, Staphylococcus aureus played an important role in infection of ostriches. Isolates from birds had arthritis and conjunctivitis were highest at winter season at birds of 10 month age (21.74\%) followed by summer at birds of 41/2 month age (16.13\%), while spring was the least $(6.25 \%)$ at age of $11 / 2$ month. All isolates were identified as $S$. aureas. Some cases gave mixed infection.
\end{abstract}

\section{INTRODUCTION}

Although, Perelman (1999) and Huchzermeyer (1998) throw light on the diseases of ostriches yet. The information on the infectious diseases of ostriches is not enough. The use commercial enzyme linked immunosorbant assay (ELISA) lists to detect antibodies of infectious diseases in ostriches has not been possible, because anti-chicken antibodies do not react with ostrich immunoglobulins, and anti-ostrich antibodies are not generally available (Cadman et al., 1994a).

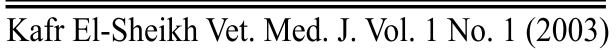


Knowledge of the immunoglobulins of domestic animals has permitted the development of serological tests, which have become widely used for the diagnosis and monitoring of infectious diseases. Although the ostrich industry is rapidly expanding in both third and first -world countries, serological tests for detecting infectious agents are not in common use, partly because specific reagents for such tests are not commercially available.

Cadman et al.,(1994b)isolated and characterized the immunoglobulins in ostrich sera. Unfortunately, ostrich in Matroeh more or less suffered form respiratory diseases and conjunctivits and synovitis.

Therefore, the aim of the present work was to study the mycoplasma, and staphylococcus infection and characterization of the immunoglobulins in these affected ostrich sera.

\section{MATERIALS \& METHODS}

\section{Samples:}

Nasal cleft,conjunctival,synovial and serum samples were collected from ostriches showed severe respiratory symptoms, conjunctivitis and synovitis.

\section{II.Media:-}

a) For mycoplasma

Prepared and used as described by Frey et al. (1968).

b) For staphylococcus blood agar media (Difco).

\section{III.Biochemical characterization of the isolated strains of mycoplasma}

Were carried out according to Erno and Stiplsovits (1973). The isolate was serologically identified by growth inhibition test as described by Clyde (1964).

\section{Biochemical reactions of isolated staphylococcus strains:-}

Were carried out according to MacFaddin (1980). Using the following reactions haemolysis on blood agar, catalase, coaglase DNase tests and sugar fermentation tests. 
V. Serum samples were examined by:

A)Serum plate agglutination (SPA) was used for the detection of $M$. gallisepticum antibodies in the collected serum samples.

B)Sodium dodecyl sulphate-polyacrylamide gel electrophoresis (SDSPAGE) was carried out as described by Laemmli (1970) to characterize the immunoglobulins in ostrich sera.

\section{RESULTS}

According to the site of infection out of 15 cases of conjunctivitis 2 (13.33) were positive for M. gallisepticum (11.76) and 7 (46.07\%) positive for $S$. aureus. Out of 83 suffered form respiratory manifestations cases $12(14.64 \%)$ were positive for $M$. gallisepticum and $4(4.81 \%)$ were positive for $S$. aureus. Out of 17 cases of arthritis $2(11.76 \%)$ were positive for M. gallisepticum and 5 (29.41\%) for S. aureus.

Table(2) shows the incidence of mycoplasma infection in ostriches. One hundred and fifteen samples (17 arthritis, 83 nasal cleft and 15 conjunctival) were collected at 21 day, 4 months, 10 months and 12 months old. We found that highest incidence of mycoplasma was at 10 months $(21.74 \%)$, followed by $(17.24 \%)$ at $7 \frac{1}{2}$ months, while it was the least at $1 \frac{1}{2}$ month $(9.38 \%)$. The highest incidence of staphylococcus infection was at 10 months $(21.74 \%)$ followed by at $4 \frac{1}{2}$ months $(16.13 \%)$ and the least incidence was at $1 \frac{1}{2}$ month $(6.25 \%)$.

Concerning biochemical characterization of the isolated strains of mycoplasma, they were digitonin sensitive, glucose positive and arginine negative. As for serological identification, the isolates were identified as Mycoplasma gallisepticum(Table2)For isolated strains of staphylococcus all isolates were positive for MacFaddin reaction, catalase and DNase as well as maltose sugar fermentation and identified as $S$. aureus.

SDS-PAGE of the diseased (by $M$. gallisepticum) and healthy cases sera revealed the increased $\gamma$-globulin in sera of diseased ostriches.

Serologically, out of 115 serum samples, 29 (25.2\%) were positive for $M$. gallisepticum antibodies as detected by serum plate agglutination test (SPA).

$\overline{\text { Kafr El-Sheikh Vet. Med. J. Vol. } 1 \text { No. } 1 \text { (2003) }}$ 
Oraby, F.A.I \& Hassan, A.M.

Table(1): Incidence of mycoplasma and staphylococcus infection in ostrich at different sites.

\begin{tabular}{||l||c||c|c||c|c||c|c||}
\hline \multirow{2}{*}{\multicolumn{1}{|c||}{ Site }} & \multirow{2}{*}{$\begin{array}{c}\text { No. } \\
\text { examined }\end{array}$} & \multicolumn{2}{c||}{$\begin{array}{c}\text { Positive for } \\
\text { mycoplasma }\end{array}$} & \multicolumn{2}{c||}{$\begin{array}{c}\text { Positive for } \\
\text { S. aureus }\end{array}$} & \multicolumn{2}{c|}{$\begin{array}{c}\text { Mixed } \\
\text { infection }\end{array}$} \\
\cline { 5 - 9 } & No. & \% & No. & \% & No. & \% \\
\hline \hline Arthritis & 17 & 2 & 11.76 & 5 & 29.41 & 2 & 11.76 \\
\hline Nasal cleft & 83 & 12 & 14.46 & 4 & 4.81 & - & - \\
\hline Conjunctivitis & 15 & 2 & 13.33 & 7 & 46.67 & 1 & 6.67 \\
\hline Total & 115 & 16 & 13.91 & 16 & 13.91 & 3 & 2.61 \\
\hline
\end{tabular}

1- All mycoplasmal isolates were +ve for glucose and -ve for arginine.

2- All Staphylococcus isolates were positive for MacFaddin reaction, catalese and DNAse as well as maltose sugar fermentation.

3- All mycoplasmal isolates give large zone of inhibition with Mycoplasma gallisepticum antisera coated discs.

Table(2):Effect of age and/or season on the incidence of mycoplasma and staphylococcus infection in ostrich.

\begin{tabular}{|c|c|c|c|c|c|c|c|}
\hline \multirow[t]{2}{*}{ Season and age } & \multirow{2}{*}{$\begin{array}{l}\text { No.of exam. } \\
\text { birds }\end{array}$} & \multicolumn{2}{|c|}{$\begin{array}{l}\text { Positive for } \\
\text { mycoplasma }\end{array}$} & \multicolumn{2}{|c|}{$\begin{array}{c}\text { Positive for } \\
\text { S. aureus }\end{array}$} & \multicolumn{2}{|c|}{$\begin{array}{c}\text { Mixed } \\
\text { infection }\end{array}$} \\
\hline & & No. & $\%$ & No. & $\%$ & No. & $\%$ \\
\hline Spring $(1 / 2$ month $)$ & 32 & 3 & 9.38 & 2 & 6.25 & - & - \\
\hline Summer $\left(4^{1} / 2\right.$ months $)$ & 31 & 3 & 9.67 & 5 & 16.13 & 1 & 3.23 \\
\hline Fall $\left(7^{1} / 2\right.$ months $)$ & 29 & 5 & 17.24 & 4 & 13.79 & 1 & 3.45 \\
\hline Winter (10 months) & 23 & 5 & 21.74 & 5 & 21.74 & 1 & 4.35 \\
\hline Total & 115 & 16 & 13.91 & 16 & 13.91 & 3 & 2.61 \\
\hline
\end{tabular}

Table(3): Serum profile of ostriches using SDS-PAGE electrophoresis.

\begin{tabular}{||l|c|c||c|c||}
\hline \multirow{2}{*}{} & \multicolumn{2}{|c||}{ Clinically Health } & \multicolumn{2}{c||}{ Had mycoplasma infection } \\
\cline { 2 - 5 } & KD & $\boldsymbol{\%}$ & KD & \% \\
\hline \hline Albumin & 43 & 51 & 45 & 42 \\
\hline $\boldsymbol{\alpha}_{\mathbf{1}}$ - Globulin & 53 & 8 & 54 & 7 \\
\hline $\boldsymbol{\alpha}_{\mathbf{2}}$ Globulin & 60 & 7 & 63 & 5 \\
\hline $\boldsymbol{B}$ - Globulin & 82 & 16 & 83 & 15 \\
\hline $\boldsymbol{\gamma}$ - Globulin & 128 & 18 & 130 & 31 \\
\hline
\end{tabular}

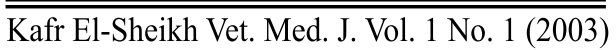


Mycoplasma Gallisepticum And Staphylococcus Aureus Infection....

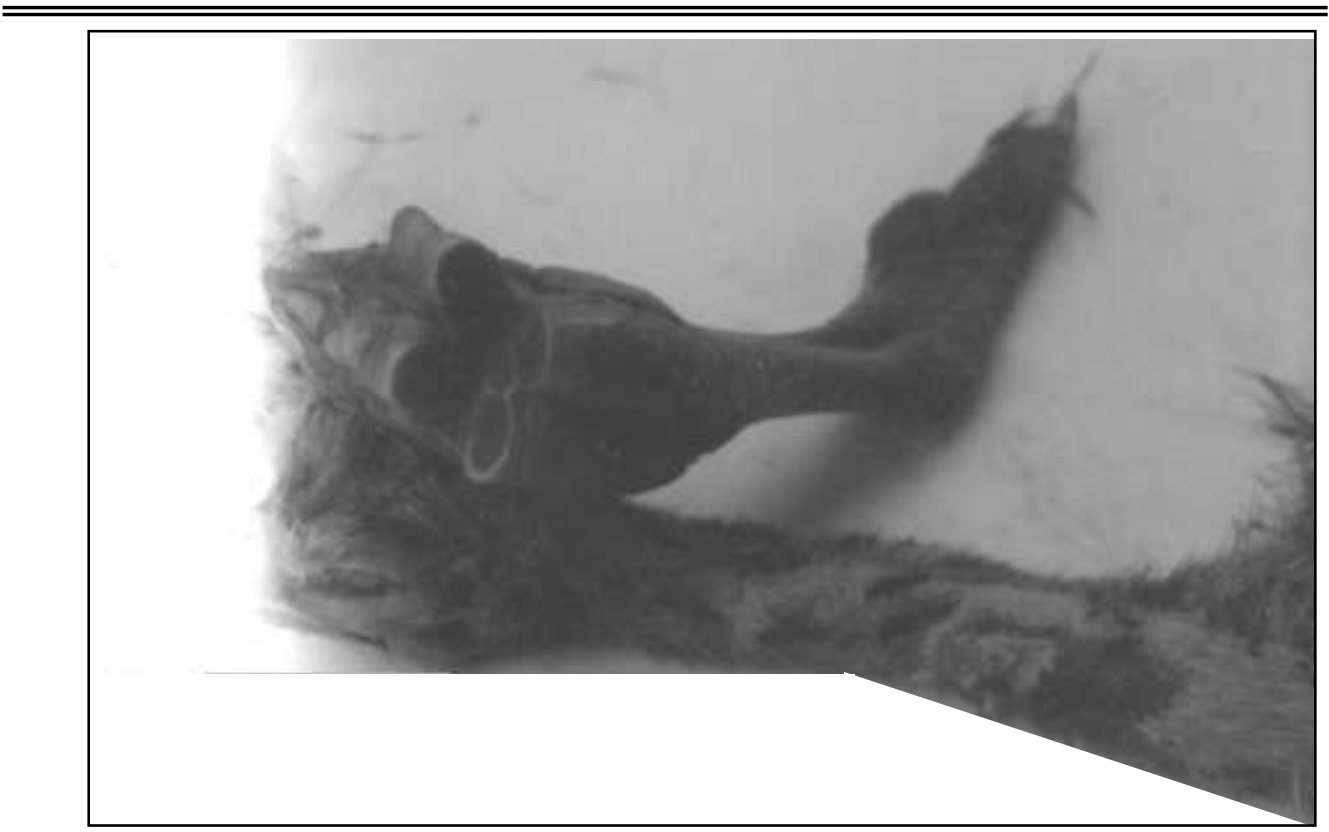

Fig (1) Arthritis in ostrich caused by Mycoplasma gallisepticum and Staphylococcus aureus.

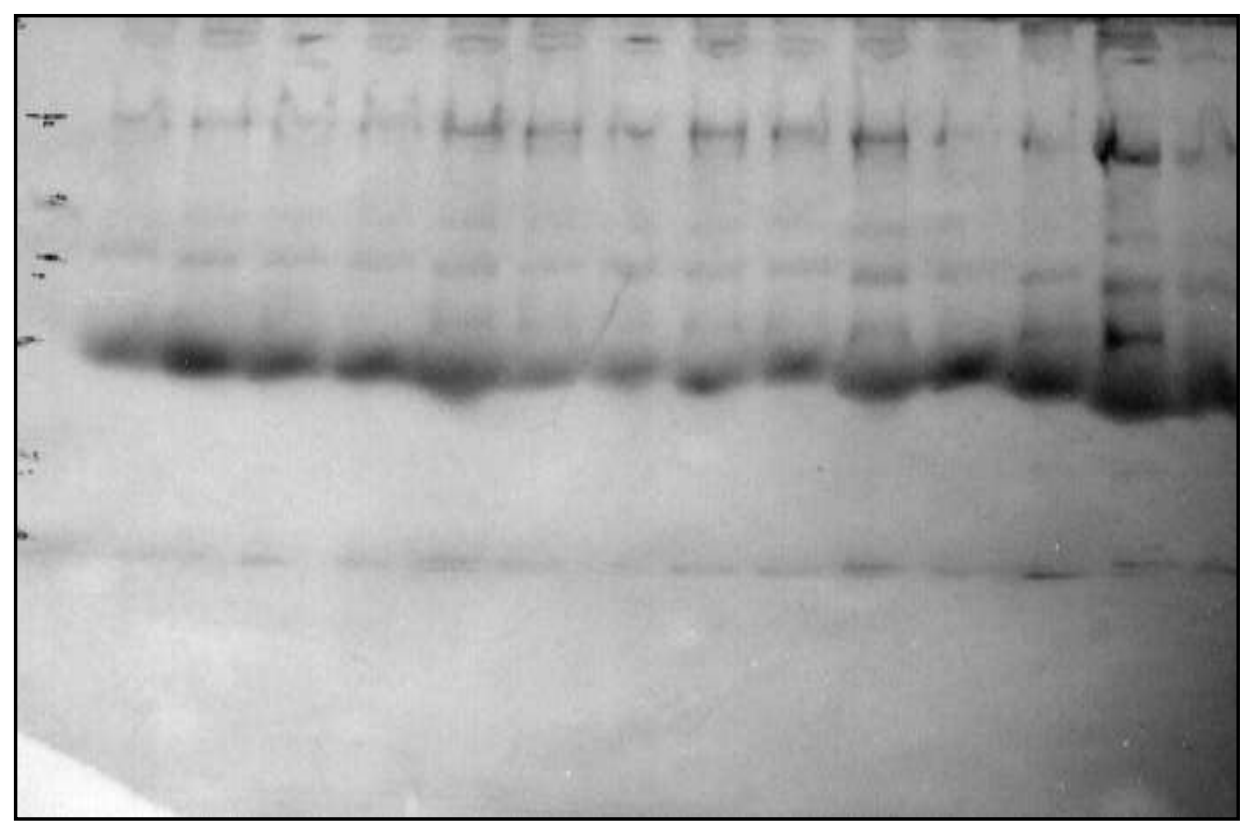

Fig (2) SDS-PAGE for serum collected from M. gallisepticum diseased and healthy ostriches. 


\section{DISCUSSION}

Mycoplasma gallisepticum (MG) is an important respiratory tract pathogen of commercial poultry and is generally regarded as an economically significant cause of disease confronting poultry production world wide (Yoder, 1991). Also, an important bacteria recorded to cause respiratory diseases and arthritis in ostrich was $S$. aureus. In the present study, M. gallisepticum was isolated from ostriches showed severe respiratory symptoms. The highest incidence of infection (21.74) was detected in winter (10 months), while in spring $\left(1 \frac{1}{2}\right.$ month) it was the least (9.38).

$S$. aureus was isolated from different cases with highest incidence in winter at age of 10 months $(21.74 \%)$ and lowest incidence in spring at age of $1 \frac{1}{2}$ month $(6.25 \%)$. Out of 115 serum samples were positive for $S$. aureus samples, 29 (25.2\%) were positive for $M$. gallisepticum by SPA test. Hartap et al., (2001) mentioned that M. gallisepticum has produced conjunctivitis eastern House Fiaches of North America, conjunctivitis produced ranged from 0 to $43 \%$, and exhibited marked seasonal fluctuation (elevation during fall and winter and lower disease prevalence during the breeding season). Also, Korbel (1991) revealed that M. gallisepticum cause occular manifestation in ostriches.

Perelman (1991) Shivaprasad (1993) and Huchzermeyer (1998) recorded that $M$. gallisepticum and $S$. aureus were isolated from respiratory diseased ostriches.

Generally, characterization of the serum immunoglobulins classes it coincide with Cadman et al. (1994).

\section{REFERENCES}

- Cadman, H.F.; Kelly, P.J.; Zhou, R.; Daveluar,F.and Mason,P.R. (1994): "A serosurvey using enzyme linked immunosorbent assay for antibodies against poultry pathogens in ostriches (Struthio camelus) from Zimbabwe" Avian dis., 38, 621-625.

- Cadman, H.F.; Kelly, P.J.; Dilsunifura, M.; Carter, S.D.; Azwai, S.M. and Wright, E.P.(1994b): "Isolation and characterization of serum immunoglobulin classes of the ostrich (struthio camelus)" Avian Dis., 38, 616-620.

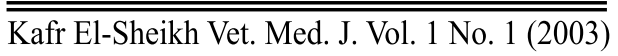


Mycoplasma Gallisepticum And Staphylococcus Aureus Infection....

- Clyde, W.A. Jr. (1964):"Mycoplasma species identification based upon growth inhibition by specific antisera." J. Immunol., 92, 958-965.

- Erno, H. and Stipkovits, L. (1973):"Bovine mycoplasmas I. cultural and biochemical studies." Acta Vet. Scand., 14, 436-449.

- Frey, M.C.; Hanson, R.P. and Anderson, D.P. (1968):"A medium for the isolation of avian mycoplasma." Am. J. Vet. Res., 29: 2164-2171.

- Hartup, B.K.; Biclasl, J.M.; Dhondt, A.A.; Ley, D.H. and Kollias, G.V. (2001):"Dynamics of conjunctivitis and Mycoplasma gallisepticum infections in House Finches." American Ornithlogistis Union, The AUK, April 2001 V. 118 i2 p. 327.

- Huchzermeyer, F.W. (1998):"Diseases of ostriches and other Ratites" P. 22, Agricultural Research Council; Pretoria, South Africa.

- Korbel, R.(1991):"Ocular manifestation of systemic diseases in birds proceedings of the European chapter of the Association of Avian" Veterinarians $157-165$.

- Laemmli, U.K. (1970):"Cleavage of structural proteins during the assembly of the head of bacteriophage $\mathrm{T}_{4}$ " Nature, 227, 680-685.

- Macfadin, J.(1980): "Biochemical tests for identification of medical bacteria." $2^{\text {nd }}$ Ed., Williams and Wilkins, Co. USA.

- Perelman, B. (1991):"Medical problems observed in ostriches under intensive conditions proceedings of the European chapter of the Association of Avian" Veterinarians 300-302.

- Shivaprasad, H.L. (1993):"Neonatal mortality in ostriches an overview of possible cases" Association of Avian, Veterinarians proceedings 282-293.

- Yoder, H.W.Jr.(1991):"Mycoplasma gallisepticum infection. In: Diseases of poultry 9th Ed B.W. Calnek, H.J. Barnes, C.W. Beard, W.M. Reid, and A. W.Jr. Yoder, Eds. Iowa state" University Press, Ames, Iowa, PP. 198-212.

$\overline{\text { Kafr El-Sheikh Vet. Med. J. Vol. } 1 \text { No. } 1 \text { (2003) }}$ 


$$
\begin{aligned}
& \text { عدوى الميكوبلازما جاليسبتكم و الميكروب العنقودى الذهبى } \\
& \text { فى النعام بمحافظه مطروح } \\
& \text { د. عبد الواحد محمود حسن و د.فتحى عرابى }
\end{aligned}
$$

تم فحص مزارع النعام فى محافظة مطروح لتحديد الإصـابة بالميكوبلازمـا. وقد أمكن عزل

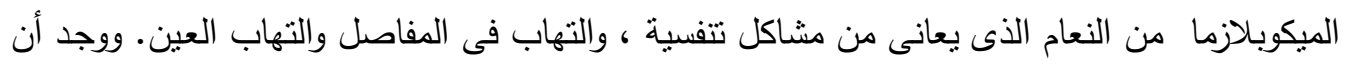

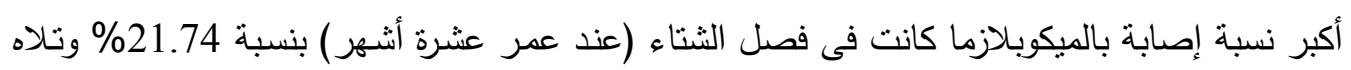

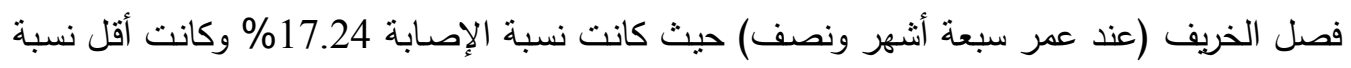

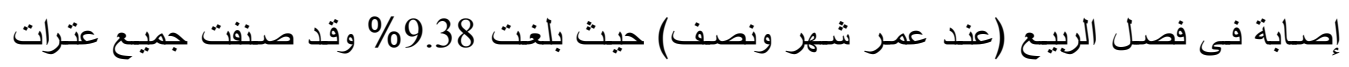

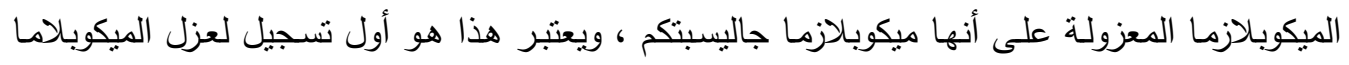
جاليسبتكم من النعام بمصر .

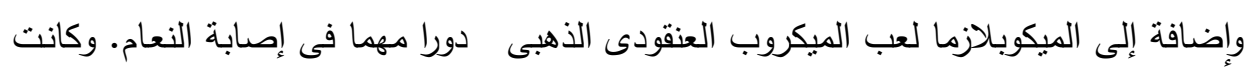

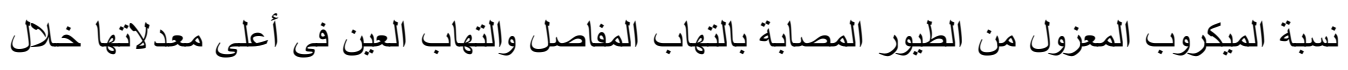

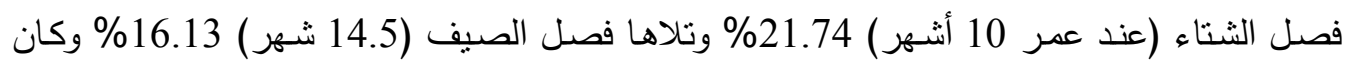
فصل الربيع هو أفضل الفصول بالنسبة للإصابة (عند عمر 1.5 شهر ) حيث بلغت 6.25\%. وتم تصنيف العترات المعزولة على أنها الميكروب العنقودى الذهبى .وقد وجدت أيضا إصابات مشتركة. 